\title{
Ability of different edible fungi to degrade crop straw
}

\author{
Liang Huang, Ning Sun, Litong Ban*, Yu Wang and Hongpeng Yang
}

\begin{abstract}
Extracellular enzymes play an important role in the growth and development of edible fungi. Extracellular enzyme activities have also become an important object of measurement. In this study, Agaricus brunnescens Peck, Coprinus comatus, and Pleurotus ostreatus were compared in terms of their enzyme production in liquid-and solid-state fermentation. Differences in the ability of various types of edible fungi to utilize biomass raw materials were analyzed by monitoring the fiber degradation rate during crop straw degradation, and changes in their cellulolytic enzyme systems during growth and metabolism were discussed. This study provided insights into the changes in the lignocellulose degradation ability of edible fungi during their growth and facilitated the discovery of new approaches to accelerate their growth in culture.
\end{abstract}

Keywords: Edible fungi, Crop straw, Lignocellulolytic enzymes

\section{Introduction}

Edible fungi have been appreciated for their flavor and texture and recognized as a nutritious food and important source of bioactive compounds with medicinal value (Cheung et al. 2003). Certain fungal species have been used for their medicinal properties for over 2000 years, and their bioactive compounds that act as immunomodulatory and exhibit anticancer activities have been isolated (Sadler 2010). Since the 1960s, studies have explored the chemical constituents and pharmacological effects of edible fungi and confirmed the special biological effects and medicinal values of edible fungi at a molecular level. For example, polysaccharides and proteoglycans in edible fungi play important roles in biological activities (Laatsch 1992; Mei and Zhang 2007; Ye et al. 2011).

With current scientific focus on functional foods and functional ingredients, the contribution of edible fungi to this category of foods has been investigated. Edible fungi are cultured in media that usually consist of sawdust, cottonseed husk, wheat bran, and other substances. They also contain lignocelluloses, such as cellulose, hemicellulose, and lignin, which can induce edible fungi

*Correspondence: banlitong@126.com

College of Agronomy and Resources Environment, Tianjin Agricultural University, Tianjin 300384, China to secrete cellulose, hemicellulose, and other extracellular hydrolases (Huai-Liang 2010; Lechner and Papinutti 2006; Rani et al. 2008). Lignocellulolytic enzymes are carbohydrate-active enzymes that perform important roles in the carbohydrate metabolism of organisms. Lignocellulolytic enzyme secretion during the fermentation of edible fungi is a necessary physiological function for the transformation of lignocellulolytic matrix during fungal growth (Elisashvili et al. 2002). Therefore, the decomposition degree and efficiency of edible fungi can be understood by detecting the extracellular enzyme activities of edible fungi under different conditions to provide a rapid and enhanced environment for hyphal and sporophore growth. We could understand the trend of changes in the extracellular enzyme activities of edible fungi from the aspect of edible fungal growth. As such, we can further explore the pharmacological activity of edible fungi and improve cultivation techniques.

Crop straw is difficult to be used as an industrial raw material and feed because the cell wall of a plant stem contains lignocellulose (Parisi 1989; Schimpf et al. 2013). Lignocellulose is one of the most widely distributed organic compounds worldwide and has become a limiting factor in the global carbon cycle because of its low degradation efficiency. Traditional lignocellulosic biomass treatment processes include biomass pretreatment, 
pretreated biomass hydrolysis, fermentation, and biofuel recovery (Muktham et al. 2016). These operations are complex and strict, and the production and purification of lignocellulose are complex and low yielding (Howard et al. 2003). Therefore, the cultivation of edible mushrooms is a crucial method for the bioconversion of many types of low-value lignocellulosic wastes (Choudhary et al. 2009).

In the present study, the activities of extracellular enzymes, such as carboxymethylcellulase (CMCase) and laccase, and the cellulose degradation rates of three kinds of edible fungi, namely, Coprinus comatus, Agaricus brunnescens Peck and Pleurotus ostreatus, were investigated under different culture conditions. Suitable strain and appropriate culture cycle were also determined by analyzing the trend of changes in the extracellular enzyme activities of edible fungi that could be used as biological agents for the organic recycling of agricultural wastes.

\section{Materials and methods Microorganisms}

Three strains of edible fungi, namely, $C$. comatus, $A$. brunnescens and $P$. ostreatus, were obtained from technology research \& development center for edible fungus of Tianjin agricultural university, and maintained on Potato Dextrose Agar (PDA) solid medium at $25^{\circ} \mathrm{C}$.

\section{Culture conditions and preparation of enzyme source}

Until the mycelium was full, liquid-state fermentation was carried out in $500 \mathrm{~mL}$ conical flasks containing $100 \mathrm{~mL}$ of liquid fermentation medium $(5 \mathrm{~g} / \mathrm{L}$ amylum solani, $20 \mathrm{~g} / \mathrm{L}$ glucose, $10 \mathrm{~g} / \mathrm{L}$ straw, $2 \mathrm{~g} / \mathrm{LKH}_{2} \mathrm{PO}_{4}, 1 \mathrm{~g} /$ $\mathrm{LMgSO}_{4}, 0.1 \mathrm{~g} / \mathrm{L} \mathrm{CuSO}_{4}$, and $2 \mathrm{~g} / \mathrm{L}$ peptone at $\mathrm{pH} 4-6$ ). Water in the $A$. brunnescens medium was composed of the filtrate of $30 \%$ peat soil boiled for $30 \mathrm{~min}$. The edible fungi were cultured at $25{ }^{\circ} \mathrm{C}$ and shaken at $120 \mathrm{rpm}$ for 10 days. On day 3, $2 \mathrm{~mL}$ of each sample was extracted and centrifuged at $4000 \mathrm{rpm}$ for $20 \mathrm{~min}$. The supernatant was obtained for enzyme activity determination.

Solid-state fermentation was conducted in a wheat grain medium containing $92 \%-93 \%$ wheat, $5 \%$ bran, and $2 \%$ gypsum. In the $C$. comatus and $A$. brunnescens culture media, $1 \%$ cow dung was added. In the A. brunnescens medium, water was composed of the filtrate of $30 \%$ peat soil boiled for $30 \mathrm{~min}$. The edible fungi were cultured at $25{ }^{\circ} \mathrm{C}$ for $15-20$ days. When the mycelium grew to $25 \%$, $50 \%, 75 \%$, and $100 \%$ of the culture bottle, $5 \mathrm{~g}$ of the sample was ground and transferred into $20 \mathrm{~mL}$ of water and extracted at $30{ }^{\circ} \mathrm{C}$ for $2 \mathrm{~h}$. The solution was filtered and used for enzyme activity determination.

\section{CMCase and xylanase activity assay}

CMCase and xylanase activities were determined in accordance with previously described methods (Wood and Bhat 1988) with some modifications. In brief, $0.5 \mathrm{~mL}$ of appropriately diluted enzyme was extracted with $1.5 \mathrm{~mL}$ of $1 \%$ CMC citric acid buffer (1\% beech xylanase buffer) at $\mathrm{pH} 5.0$ and $40{ }^{\circ} \mathrm{C}$ for $30 \mathrm{~min}$. The reaction was terminated by adding $3 \mathrm{~mL}$ of 3,5-dinitrosalicylic acid reagent and boiled for $15 \mathrm{~min}$. Then, 1 $\mathrm{mL}$ of $40 \%$ sodium potassium tartrate was added, and absorbance was measured at $540 \mathrm{~nm}$ against the blank (without enzyme filtrate). One unit of CMCase activity was expressed as $1 \mu \mathrm{mol}$ of glucose/xylose liberated from each milliliter of enzyme per minute under assay conditions.

\section{Laccase activity assay}

The laccase activity was determined spectrophotometrically at $436 \mathrm{~nm}\left(\varepsilon 436=29,300 \mathrm{M}^{-1} \mathrm{~cm}^{-1}\right)$ for 5 min by using $\mathrm{ABTS}$ as a colorimetric substrate and an assay mixture containing $1 \mathrm{mM}$ ABTS in $0.2 \mathrm{M}$ sodium citrate buffer at $\mathrm{pH} 4.0$ and incubated for $15 \mathrm{~min}$ at $30^{\circ} \mathrm{C}$ before the measurement was performed. One activity unit (U) was defined as the amount of enzyme that oxidized $1 \mu \mathrm{mol}$ of ABTS per minute at $25^{\circ} \mathrm{C}$, and the activities were expressed in units per liter.

\section{Cellulose content determination}

Before and after fermentation was performed, $1 \mathrm{~g}$ of the samples was added to $100 \mathrm{~mL}$ of neutral detergent at $100{ }^{\circ} \mathrm{C}$ for $30 \mathrm{~min}$. The filtrate was washed with $95 \%$ ethanol, anhydrous ethanol, and acetone until clear and then oven dried.

The residue was added to $2 \mathrm{~mol} / \mathrm{L}$ hydrochloric acid solution at $100{ }^{\circ} \mathrm{C}$ for $30 \mathrm{~min}$. The filtrate was washed with 95\% ethanol, anhydrous ethanol, and acetone until clear and oven dried. The residue quality was weighed as $\mathrm{W}_{1}$.

The residue was added to precooled $72 \%$ sulfuric acid and degraded for $4 \mathrm{~h}$ at room temperature. Distilled water was then added to wash the residue to $\mathrm{pH} 6.5$, and the dry residue quality was weighed as $\mathrm{W}_{2}$. The content of cellulose was $\mathrm{W}_{1}-\mathrm{W}_{2}$.

\section{Data statistics}

Comparisons between groups were performed by oneway analysis of variance followed by Bonferroni post hoc test (SPSS software package version 17.0, SPSS Inc., Chicago, IL, USA). The level of significance was set at $\mathrm{P}<0.05$. 


\section{Results}

\section{Intracellular enzyme activity of $C$. comatus}

We compared the intracellular enzyme activities of $C$. comatus, $A$. brunnescens, and P. ostreatus in liquid-and solid-state fermentation. The results showed that the CMCase activity of $C$. comatus reached the maximum on day 5 during the liquid-state fermentation. The highest enzyme activity was $29.3538 \mathrm{U}$, and the enzyme activity plateaued on days 6 and 7 (Fig. 1a). The laccase activity of $C$. comatus reached its maximum value on day 7 . The highest enzyme activity was $25.3129 \mathrm{U}$, and the enzyme activity remained low on the remaining days (Fig. 1b).

Figure 2a shows that the CMCase activity of $C$. comatus remained low during solid-state fermentation, and one of the samples reached its maximum value on days 9-11. The mycelial area reached $75 \%$, and the enzyme activity was $3.666 \mathrm{U}$. The laccase activity of $C$. comatus continuously increased and peaked at $62.5427 \mathrm{U}$ on day 12 (Fig. 2b). The xylanase activity of $C$. comatus was high at the early stage of fermentation, and the highest enzyme activity was $1.3306 \mathrm{U}$, which began to decrease after 12 days (Fig. 2c).

\section{Intracellular enzyme activity of $A$. brunnescens}

We compared the intracellular enzyme activity of $A$. brunnescens under different fermentation conditions by detecting the activities of CMCase, laccase, and xylanase. Figure 3a shows that the CMCase activity of $A$. brunnescens peaked on day 5 (19.8819 U) during liquidstate fermentation, and the activity increased slightly on days 9 and 10. The laccase activity of $A$. brunnescens increased continuously during fermentation and reached $25.4266 \mathrm{U}$ on day 10 (Fig. 3b).

During solid-state fermentation, the CMCase activity of $A$. brunnescens was high at the initial stage of fermentation. The highest enzyme activity was up to $1.9905 \mathrm{U}$, and the enzyme activity decreased slightly during fermentation (Fig. 4a). In Fig. 4b, the laccase activity of $A$. brunnescens reached the highest level (74.5165 U) on days 11-13 but continuously decreased at the late stage. The xylanase activity of $A$. brunnescens was high on days 13,14 , and 16 , and the highest was $1.8035 \mathrm{U}$ (Fig. 4c).
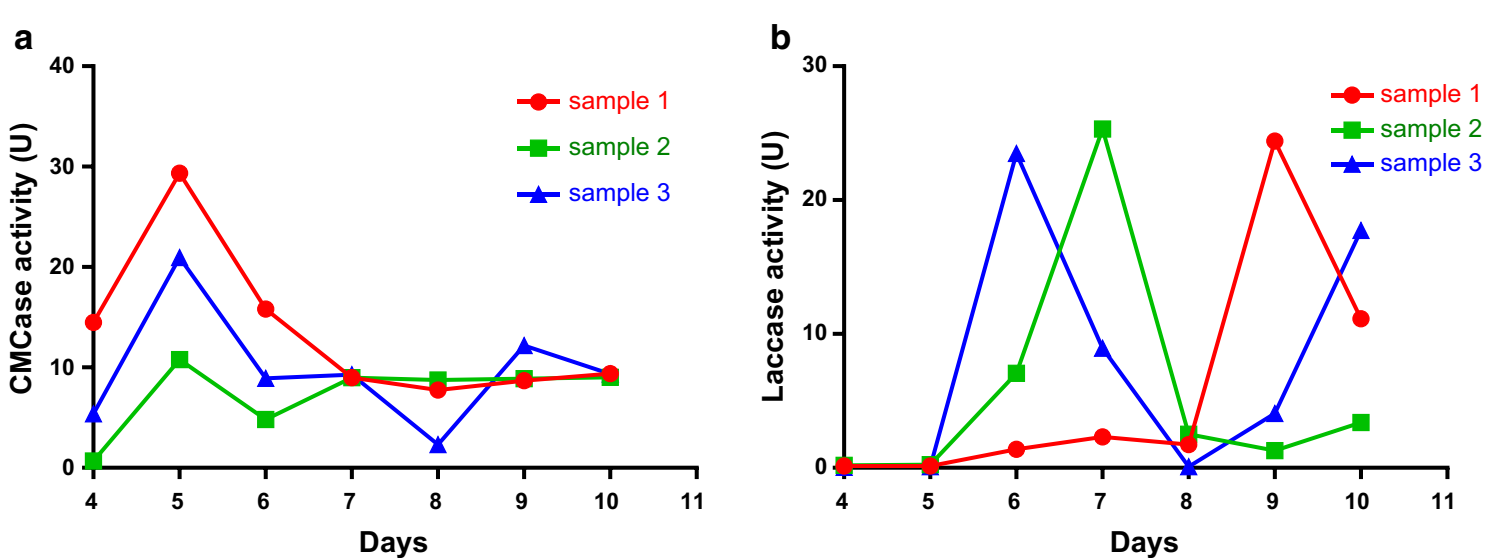

Fig. 1 a CMCase activity of C. comatus during liquid-state fermentation. b Laccase activity of C. comatus during liquid-state fermentation
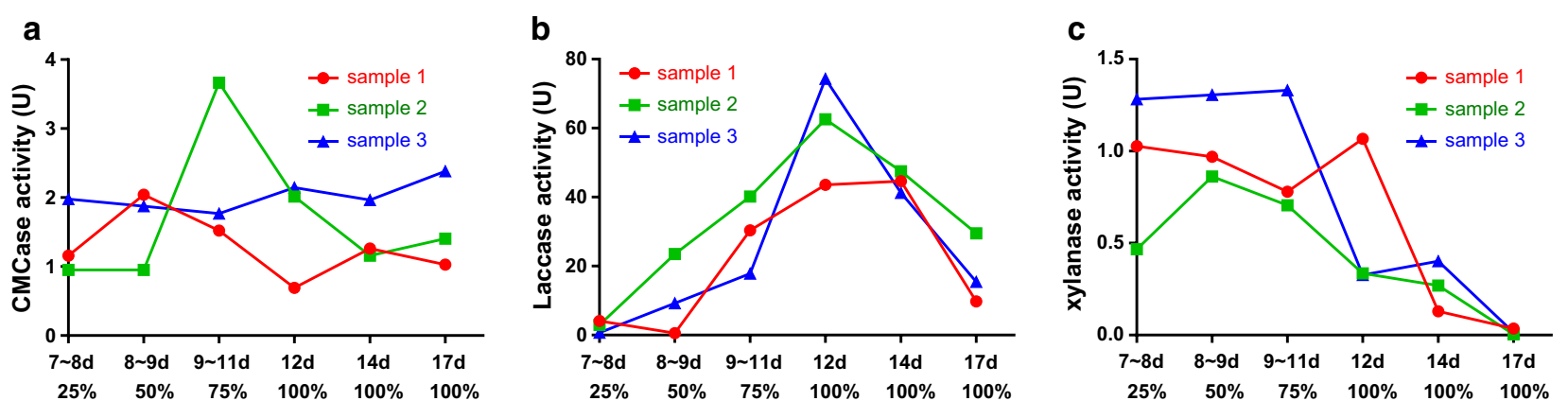

Fig. 2 a CMCase activity of C. comatus during solid-state fermentation. b Laccase activity of C. comatus during solid-state fermentation. c Xylanase activity of $C$. comatus during solid-state fermentation 


\section{Intracellular enzyme activity of $P$. ostreatus}

The activity of the intracellular enzymes of $P$. ostreatus was determined under solid-and liquid-state fermentation. During liquid-state fermentation, the activity of CMCase peaked on day 6. The highest enzyme activity was $28.1975 \mathrm{U}$, and the activity increased slightly on days 9 and 10 (Fig. 5a). Figure 5b shows that the laccase activity remained low on the first 7 days and increased to $34.8692 \mathrm{U}$ on day 10.

The CMCase activity of $P$. ostreatus increased slowly at the early stage of solid-state fermentation and peaked at $7.2657 \mathrm{U}$ on days $11-13$ (Fig. 6a). The laccase activity of $P$. ostreatus began to increase gradually on days 8 and 9, peaked at $80.1479 \mathrm{U}$ on day 12 , and decreased slowly
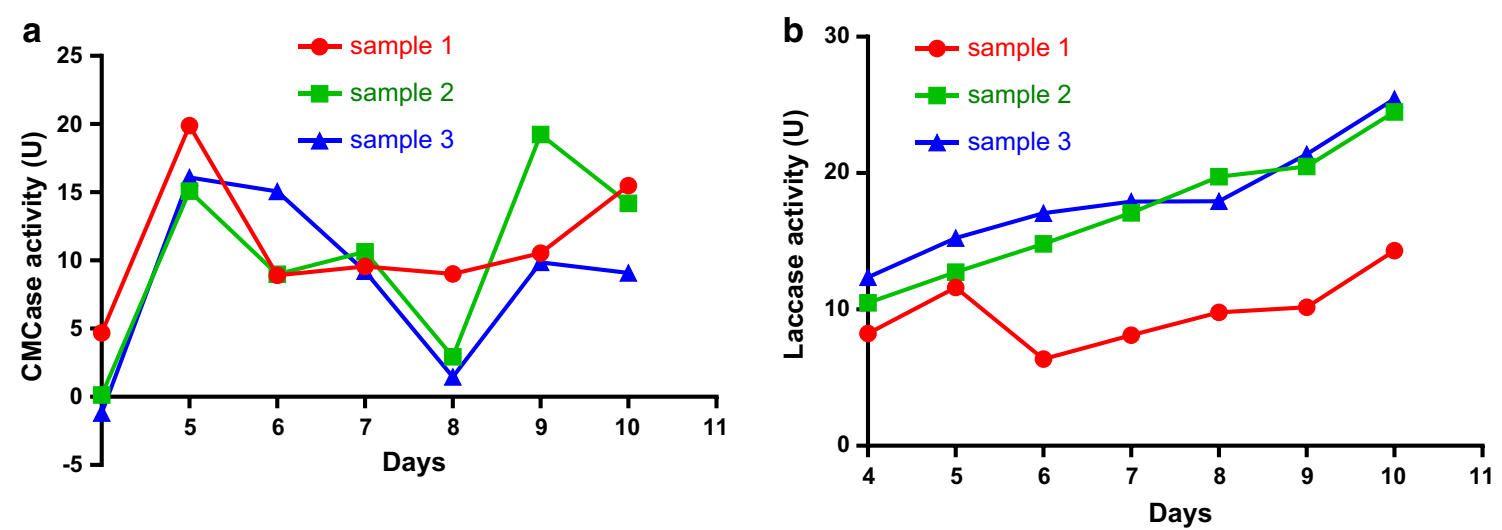

Fig. 3 a CMCase activity of A. brunnescens during liquid-state fermentation. b Laccase activity of A. brunnescens during liquid-state fermentation
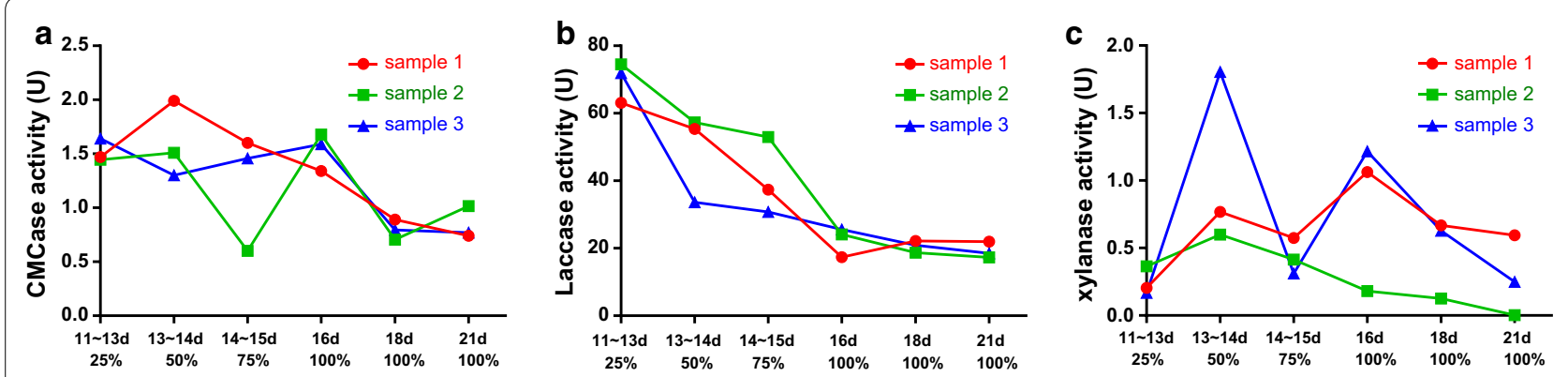

Fig. 4 a CMCase activity of A. brunnescens during solid-state fermentation. $\mathbf{b}$ Laccase activity of A. brunnescens during solid-state fermentation. $\mathbf{c}$ Xylanase activity of $A$. brunnescens during solid-state fermentation
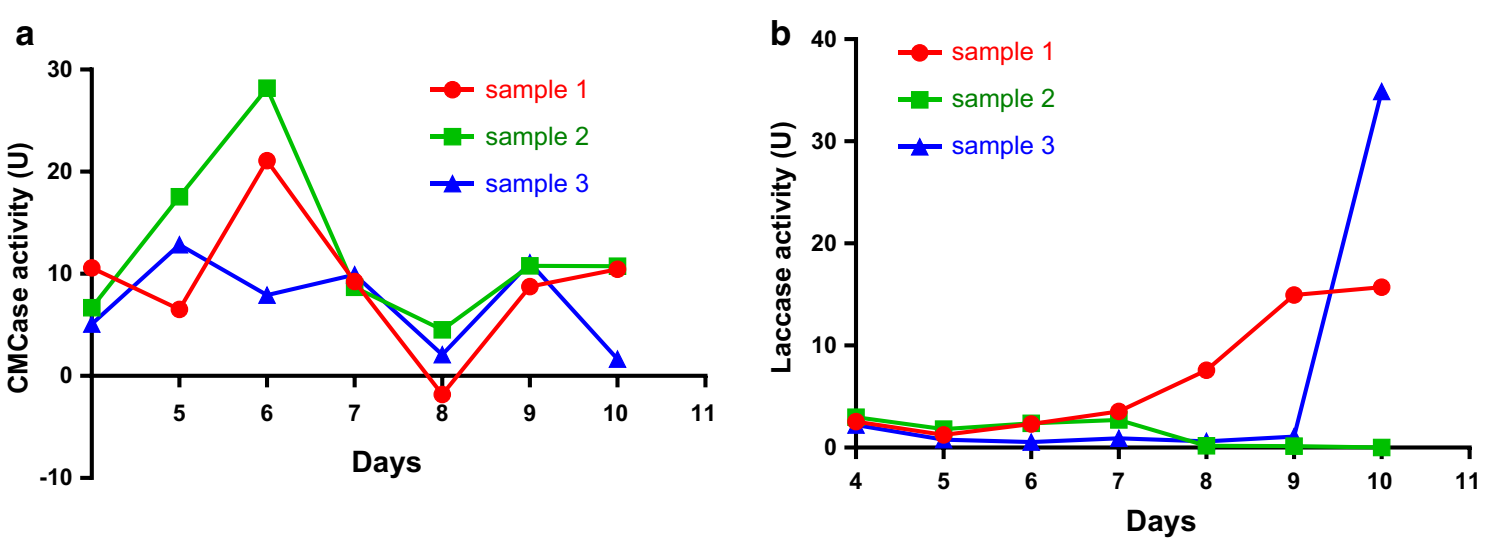

Fig. 5 a CMCase activity of $P$. ostreatus during liquid-state fermentation. b Laccase activity of $P$. ostreatus during liquid-state fermentation 

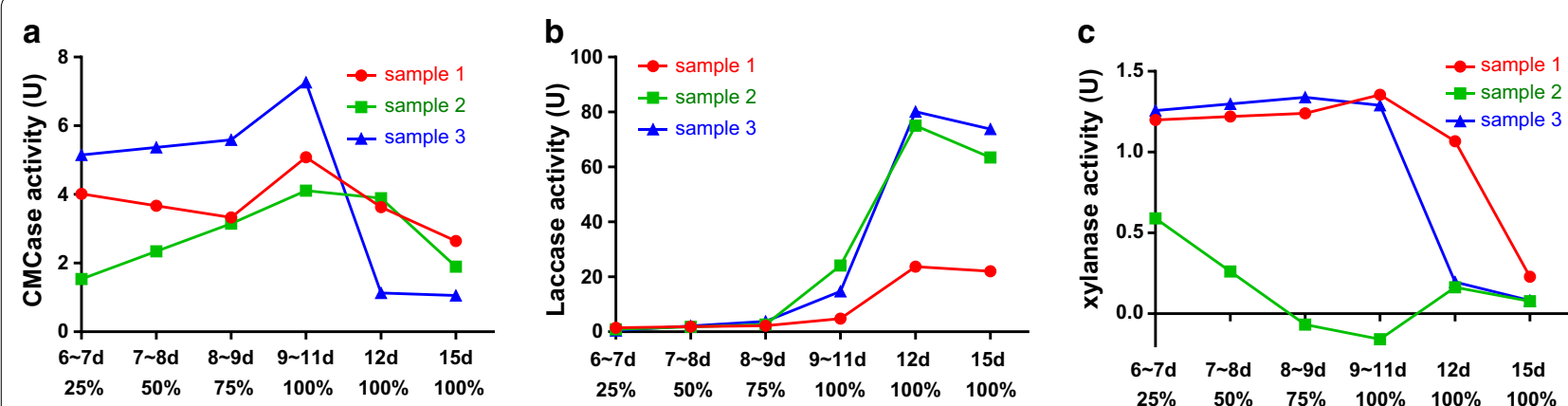

Fig. 6 a CMCase activity of $P$. ostreatus during solid-state fermentation. $\mathbf{b}$ Laccase activity of $P$. ostreatus during solid-state fermentation. $\mathbf{c} X y$ lanase activity of $P$. ostreatus during solid-state fermentation

Table 1 Cellulose degradation rate of three kinds of edible fungi

\begin{tabular}{cllll}
\hline & $\begin{array}{l}\text { Before } \\
\text { fermentation } \\
\text { (\%) }\end{array}$ & $\begin{array}{l}\text { After } \\
\text { fermentation }\end{array}$ & $\begin{array}{l}\text { Cellulose } \\
\text { degradation } \\
\text { rate (\%) }\end{array}$ \\
\hline Coprinus comatus & 28.64 & 1 & $21.02 \%$ & 25.24 \\
& & 2 & $20.68 \%$ & \\
& & 3 & $22.53 \%$ & \\
Agaricus brunnes- & 25.03 & Average & $21.41 \%$ & \\
cens Peck & & 2 & $13.95 \%$ & 37.75 \\
& & 3 & $14.86 \%$ & \\
Pleurotus ostreatus & 28.64 & 1 & $17.94 \%$ & \\
& & Average & $15.58 \%$ & \\
& & 2 & $21.37 \%$ & 21.05 \\
& & 3 & $20.67 \%$ & \\
\hline & & Average & $22.61 \%$ & \\
\hline
\end{tabular}

(Fig. 6b). Figure 5a illustrates that the xylanase activity remained high before days 9-11 (1.3553 U) and began to decrease after 11 days.

\section{Cellulose degradation rates of $C$. comatus, A. brunnescens, and $P$. ostreatus}

We analyzed the data and obtained the degradation rate of cellulose (Table 1) by comparing the cellulose contents of the three edible fungi before and after fermentation. The results showed that the degradation rates of cellulose were as follows: C. comatus, 25.24\%; A. brunnescens, 37.75\%; and P. ostreatus, $21.05 \%$.

\section{Discussion}

Crop straw is a rich renewable resource, but it causes environmental pollution that is considered a major problem in modern agriculture (Novaes et al. 2010; Sanderson 2011). Lignocellulose, which is abundant in crop straw, is the main component limiting straw degradation (Ćilerdžić et al. 2017). Laccase and xylanase are the main components of lignocellulase. Microbial strains, such as fungi, can effectively degrade lignocellulose by secreting lignocellulosin-degrading enzymes through the oxidative cleavage of chemical bonds (Liew et al. 2011; Yang et al. 2011; Zeng et al. 2006). Edible fungi have become a new field in the development of natural drug resources because of their special biological effects and medicinal values (Chihara et al. 1970; Petrovai and Diana 1970). Therefore, determining the appropriate culture conditions for edible fungi can alleviate the difficulty in degrading lignocellulose and promote the growth of edible fungi.

In the present study, the extracellular enzyme levels of three edible fungi, namely, C. comatus, A. brunnescens, and $P$. ostreatus were determined under different culture conditions. The results showed that the enzyme activity in liquid-state fermentation was better than that in solid-state fermentation. The enzyme activity peaked on days 5 and 6 , and the peak activity of $C$. comatus could reach 29.3538 U. For the laccase activity, solid-state fermentation was better than liquidstate fermentation, and the enzyme activity peaked on days 8-12. The highest laccase activity of $P$. ostreatus was 80.1479 U. Furthermore, the highest xylanase activity of A. brunnescens was $1.8035 \mathrm{U}$ observed on days 13-14. The degradation rate of cellulose was the highest $(21.05 \%)$. This study analyzed the activities of extracellular enzymes of edible fungi under different conditions to understand the pattern of the extracellular enzyme secretion of edible fungi, to determine the enhanced culture conditions, and to improve the yield of the three kinds of edible fungi. Increasing the secretion of lignocellulase can maximize edible fungi to degrade crop straw. Further studies on nutrient components and combinations can be performed to optimize the enzyme production levels and degradation ability of crop stalks. 


\section{Authors' contributions}

LH performed experiments and wrote the manuscript. LTB designed experiments and directed experiments. NS, YW and HPY helped with the experimentation. All authors read and approved the final manuscript.

\section{Competing interests}

The authors declare that they have no competing interests.

\section{Availability of data and materials}

The dataset supporting the conclusions of this article is included within the article. All data are fully available without restriction.

\section{Consent for publication}

Not applicable.

\section{Ethics approval and consent to participate}

Not applicable.

\section{Funding}

This work was financially supported by the Innovation Team of Tianjin Vegetables Research System (ITTVRS2017015) and the Tianjin Municipal Special Program of Talents Development for Excellent Youth Scholars (TJTZJH-QNBJRC-2-12)

\section{Publisher's Note}

Springer Nature remains neutral with regard to jurisdictional claims in published maps and institutional affiliations.

Received: 18 September 2018 Accepted: 31 December 2018 Published online: 07 January 2019

\section{References}

Cheung LM, Cheung PCK, Ooi VEC (2003) Antioxidant activity and total phenolics of edible mushroom extracts. Food Chem 81(2):249-255

Chihara G, Hamuro J, Maeda Y, Arai Y, Fukuoka F (1970) Fractionation and purification of the polysaccharides with marked antitumor activity, especially lentinan, from Lentinus edodes (berk.) sing.(an edible mushroom). Cancer Res 30(11):2776-2781

Choudhary M, Dhanda S, Soni G (2009) Lignocellulolytic enzyme activities and substrate degradation by Volvariella volvacea, the paddy straw mushroom/Chinese mushroom. Indian J Agric Res. 43(3):223-226

Ćilerdžić J, Galić M, Vukojević J, Bräeski I, Stajiä M (2017) Potential of selected fungal species to degrade wheat straw, the most abundant plant raw material in Europe. BMC Plant Biol 17(Suppl 2):249

Elisashvili V, Kachlishvili E, Tsiklauri N, Khardziani T, Bakradze M (2002) Physiological regulation of edible and medicinal higher basidiomycetes lignocellulolytic enzyme activity. Int J Med Mushroom 4(2):159-166
Howard R, Abotsi E, Rensburg EJV, Howard S (2003) Lignocellulose biotechnology: issues of bioconversion and enzyme production. Afr J Biotechnol 2:602-619

Huai-Liang MA (2010) Research on partial enzymological property of crude cellulase and xylanase from three kinds of edible fungus residues. J Anhui Agric Sci. 28:015

Laatsch H (1992) polysaccharides with antitumor activity from fungi. Pharm Unserer Zeit 21(4):159

Lechner BE, Papinutti VL (2006) Production of lignocellulosic enzymes during growth and fruiting of the edible fungus Lentinus tigrinus on wheat straw. Process Biochem 41:594-598

Liew CY, Husaini A, Hussain H, Muid S, Liew KC, Roslan HA (2011) Lignin biodegradation and ligninolytic enzyme studies during biopulping of Acacia mangium wood chips by tropical white rot fungi. World J Microbiol Biotechnol 27(6):1457-1468

Mei DU, Zhang S (2007) Mechanism of edible fungal polysaccharide on reducing blood sugar. J Microbiol. 2:022

Muktham R, Taha M, Shahsavari E, Bhargava SK, Bankupalli S, Ball AS (2016) Pongamia pinnata, seed residue-a low cost inedible resource for on-site/ in-house lignocellulases and sustainable ethanol production. Renew Energy. 103:682-687

Novaes E, Kirst M, Chiang V, Winter-Sederoff H, Sederoff R (2010) Lignin and biomass: a negative correlation for wood formation and lignin content in trees. Plant Physiol 154(2):555-561

Parisi F (1989) Advances in lignocellulosics hydrolysis and in the utilization of the hydrolyzates, vol 38. Springer, Berlin, pp 53-87

Petrovai M, Diana (1970) Functional properties of edible mushrooms. Nutrition 16:694-696

Rani P, Kalyani N, Prathiba K (2008) Evaluation of lignocellulosic wastes for production of edible mushrooms. Appl Biochem Biotech 151:151-159

Sadler M (2010) Nutritional properties of edible fungi. Nutr Bull 28(3):305-308

Sanderson K (2011) Lignocellulose: a chewy problem. Nature 474:12-14

Schimpf U, Hanreich A, Mähnert P, UnmackT, Junne S, Renpenning J, LopezUlibarri R (2013) Improving the efficiency of large-scale biogas processes: pectinolytic enzymes accelerate the lignocellulose degradation. J Sustain Energy Environ 4(53):53-60

Wood TM, Bhat KM (1988) Measuring cellulase activities. Method Enzymol 160C:87-112

Yang YS, Lu H, Yuan YL, Zhao LH (2011) Isolation and characterization of a fungus Aspergillus sp strain f-3 capable of degrading alkali lignin. Biodegr. 22(5):1017-1027

Ye LB, Zheng X, Zhang J, Tang Q, Yang Y, Wang X, Li J, Liu Y, Pan Y (2011) Biochemical characterization of a proteoglycan complex from an edible mushroom Ganoderma lucidum fruiting bodies and its immunoregulatory activity. Food Res Int 44(1):367-372

Zeng GM, Yu HY, Huang HL, Huang DL, Chen YN, Huang GH, Li JB (2006) Laccase activities of a soil fungus Penicillium simplicissimum in relation to lignin degradation. World J Microbiol Biotechnol 22:317-324

\section{Submit your manuscript to a SpringerOpen ${ }^{\circ}$ journal and benefit from:}

- Convenient online submission

- Rigorous peer review

- Open access: articles freely available online

- High visibility within the field

- Retaining the copyright to your article

Submit your next manuscript at springeropen.com 